Received date: 11-Jan-2016

Accepted date: 28-Apr-2016

Article Type: Systematic Review

\title{
The influence of obesity and body-mass index on the outcome of laparoscopic colorectal surgery: a systematic literature review
}

\section{Short title: Obesity and laparoscopic colorectal surgery}

\begin{abstract}
Alexander Hotouras ${ }^{1,2}$ BSc MSc MBBS(Lon) MRCS (Eng) MD(Res), Yolanda Ribas $^{3}$ MD PhD, Simon A Zakeri ${ }^{2}$ MBChB, MRes, Quentin M Nunes ${ }^{4} \mathrm{MS} \mathrm{PhD}$ MRCS Jamie Murphy ${ }^{5}$ PhD FRCS Chetan Bhan ${ }^{2}$ FRCS Steven D Wexner ${ }^{6}$ MD, $\mathrm{PhD}$ (Hon), FACS, FRCS, FRCS(Ed),
\end{abstract}

1. National Centre for Bowel Research and Surgical Innovation, London, UK

2. Department of Surgery, Whittington Hospital NHS Trust, London, UK

3. Department of Surgery, Consorci Sanitari de Terrassa, Terrassa (Barcelona), Spain

4. NIHR Liverpool Pancreas Biomedical Research unit, Royal Liverpool \& Broadgreen University Hospitals NHS Trust, Liverpool, UK

5. Academic Surgical Unit, Imperial College London, UK

6. Digestive Disease Center, Cleveland Clinic Florida Fort Lauderdale, Florida, USA

\section{Corresponding Author}

Alexander Hotouras BSc, MSc, MBBS (Lon), MRCS(Eng) MD(Res)

National Centre for Bowel Research and Surgical Innovation

Barts and the London School of Medicine and Dentistry

2 Newark Street, London E12AT

This article has been accepted for publication and undergone full peer review but has not been through the copyediting, typesetting, pagination and proofreading process which may lead to differences between this version and the Version of Record. Please cite this article as an 'Accepted Article', doi: 10.1111/codi.13406 This article is protected by copyright. All rights reserved. 
Category: Systematic Review Conflict of interest: None declared

\section{Authorship Credits}

All authors contributed to the literature review and the preparation of this manuscript. $\mathrm{AH}$ and YR contributed equally.

\section{ABSTRACT}

Aim: The relationship between obesity, body-mass index (BMI) and laparoscopic colorectal resection is unclear. Our object was to assess systematically the available evidence to establish the influence of obesity and BMI on the outcome of laparoscopic colorectal resection.

Method: A search of PubMed/Medline databases was performed in May 2015 to identify all studies investigating the impact of BMI and obesity on elective laparoscopic colorectal resection performed for benign or malignant bowel disease. Clinical end points examined included operation time, conversion rate to open surgery, postoperative complications including anastomotic leakage, length of hospital stay, readmission rate, reoperation rate and mortality. For patients who underwent an operation for cancer, the harvested number of lymph nodes and long-term oncological data were also examined.

Results: 45 studies were analysed, the majority of which were Level IV with only four level III case-controlled studies. Thirty comparative studies containing 23649 patients including 17895 non-obese and 5754 obese showed no significant differences between 
the two groups with respect to intraoperative blood loss, overall postoperative morbidity, anastomotic leakage, reoperation rate, mortality and the number of retrieved lymph nodes in patients operated on for malignancy. Most studies, including 15 noncomparative studies, reported a longer operation time in patients who underwent a laparoscopic procedure with the BMI being an independent predictor in multivariate analyses for the operation time.

Conclusion: Laparoscopic colorectal resection is safe and technically and oncologically feasible in obese patients. These results, however, may be different outside high volume centres of expertise.

\section{What does this paper add to the literature?}

This is the most up-to-date review of the literature demonstrating the feasibility and safety of colorectal resection in obese patients.

\section{INTRODUCTION}

Worldwide, obesity has more than doubled in the last three decades with $39 \%$ of adults currently thought to be overweight while $13 \%$ are classified as obese. ${ }^{1}$ The increased incidence is expected to continue and has implications for colorectal surgeons not only because obesity is traditionally considered a risk factor for postoperative complications but also because of the potential challenges of laparoscopy in this population. In the United Kingdom, for example, $40 \%$ of colorectal operations in $2012 \%$ were performed laparoscopically compared with only $5 \%$ in $2005 .^{2}$

The increased prevalence of laparoscopic surgery has been accompanied by a reduction in the operative risk for many patients including those with class III obesity (body-mass index $>40 \mathrm{~kg} / \mathrm{m} 2) .{ }^{3}$ The impact of obesity and body-mass index on the outcome of 
laparoscopic colorectal surgery is, however, still unknown. While some surgeons have reported that laparoscopic colectomy can be safely performed in overweight and obese patients, ${ }^{4}$ others have noted the conversion rate to open surgery, the anastomotic leakage rate and the rate of complications to be greater compared with non-obese patients. ${ }^{5-6}$ Furthermore, it has also been argued that laparoscopic colorectal resection is technically more difficult in obese patients with some even suggesting that obesity is a relative contraindication. ${ }^{6-8}$ Due to these assumptions, obesity has been an exclusion criterion in studies recruiting patients undergoing colorectal resections. ${ }^{9-10}$ The aim of this systematic review is to assess current evidence and establish the influence of obesity and body mass index on the outcome of laparoscopic colorectal resection.

\section{METHOD}

A search of PubMed and Medline databases was performed in May 2015 to identify all studies investigating the impact of body mass index (BMI) and obesity on the clinical outcome of elective laparoscopic colectomy performed for benign or malignant bowel disease. A clinical trials database (www.clinicaltrials.gov) was also searched for randomised controlled trials. The search strategy included the text terms "laparoscopic", “colorectal resection", "colectomy" "obesity" and "body-mass index". Studies assessing the impact of BMI and/or obesity on non-resectional laparoscopic colorectal procedures were excluded from the analysis. The search strategy was restricted to articles written in English, with available abstracts, only involving human adult subjects from 19802015. Selected articles were also cross-referenced by hand. Three reviewers (AH, SZ and YR) qualitatively assessed all studies using the Oxford Centre for Evidence-Based Medicine 2011 levels of evidence. Any disagreements were settled by consensus. A 
diagrammatic illustration of the search process is shown in Figure 1.

Clinical outcomes examined included operation time, conversion rate to open surgery, post-operative complications including anastomotic leakage, length of hospital stay (LOS), readmission rate, reoperation rate and mortality. Furthermore, for patients who underwent colectomy for cancer, a subanalysis was performed to assess the number of lymph nodes harvested and the disease-free and overall survival when available.

\section{RESULTS}

The literature search (Figure 1) revealed 45 studies summarised in Table 1.The majority were retrospective (level IV). Four studies were case-controlled (Level III). ${ }^{11-14}$ There were no randomised controlled trials.

Thirty studies including 23649 patients compared the outcome of obese with non-obese patients. ${ }^{4-6,11-37}$ According to the definition of obesity used in the different studies, there were 17895 non-obese and 5754 obese patients. Most studies assessed the shortterm outcome following laparoscopic colorectal surgery and only two included data on the long-term outcome. ${ }^{11,19}$ Sixteen studies reported data on the oncological results ${ }^{11}$, $15-18,20,23-27,29,31,34,36,38$, but only four included data on long-term survival. 11, 20, 23, 25 The other 15 non-comparative studies mostly assessed the relationship between BMI and conversion, the outcome after conversion or the morbidity of laparoscopic colorectal resection ${ }^{38-51}$

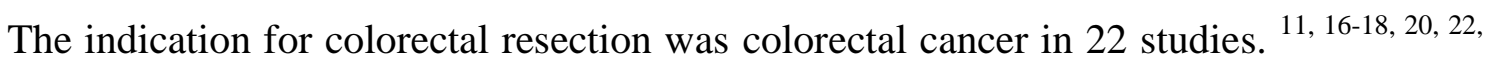
24-30, 33-34, 38, 41-45, 48 Five studies included only patients with benign aetiology such as inflammatory bowel disease or diverticular disease. ${ }^{4,19,28,40,47}$ Other studies included both benign and malignant disease $5-6,12-14,21,31,35-37,39,49-52$. In two studies the aetiology was not specified. ${ }^{15,32}$ Regarding the type of resection, eleven studies included only colonic resection ${ }^{4-5,11,17-18,33-34,36,50-52}$, nineteen colonic and rectal resection ${ }^{6,12,14-16,21-}$

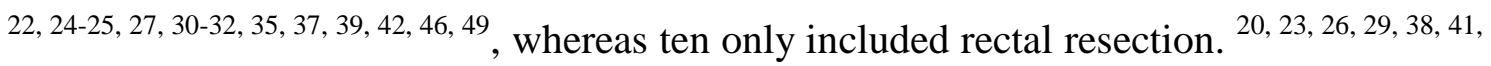
43-45, 48 Very few studies included all types of procedure including restorative 
proctocolectomy with ileal pouch anal anastomosis. ${ }^{13,19,28,40,47}$

\section{PREOPERATIVE PERIOD}

\section{Definition of obesity}

Most comparative studies defined obesity using BMI, but the cut-off point for obesity differed according to the region of origin. According to the WHO ${ }^{53}$, European and American studies considered obesity to include patients with a BMI > 30. ${ }^{4-6,11-14,19-22,}$ 25-26, 28-29, 31-32, 35-37, 39, 45 Most Asian studies defined obesity as a BMI > 25 15-16, 18, 23-24, 27, 30, 33 according to the Japanese Society for the Study of Obesity and the Steering Committee of the Regional Office for Western Pacific of WHO ${ }^{54}$, whereas others considered patients with $\mathrm{BMI}>22^{17}$, or $>28^{34}$ to be obese.

Given the evidence of an association between visceral obesity and the metabolic syndrome, three studies measured the visceral fat area (VFA). ${ }^{18,23,33}$ The VFA was measured using a cross-sectional computerised tomographic (CT) scan obtained at the level of the umbilicus or L4-L5. Two studies classified patients with VFA $\geq 130 \mathrm{~cm}^{2}$, ${ }^{33}$ as obese, and another one used VFA $\geq 100 \mathrm{~cm}^{2}$ as the cut-off point. ${ }^{18}$

\section{Comorbidity}

Co-morbidity was not systematically reported in all studies. Overall comorbid disease was significantly higher in obese patients in three studies. ${ }^{6,18,37}$ Few studies reported significantly higher incidence of hypertension ${ }^{11,18,37}$, cardiovascular disease ${ }^{14-15,19,23}$, 28, 37 or diabetes 15, 25, 28, 37 in the obese group. The American Society of Anesthesiologists (ASA) score was significantly higher in the obese group in four studies. ${ }^{12-13,29,35}$

\section{INTRAOPERATIVE PERIOD}

\section{Anaesthetic difficulties}

None of the comparative studies reported intraoperative anaesthetic difficulties or elevated peak airway pressures that required interruption of the procedure. Anaesthetic difficulties were only mentioned as the reason for conversion in very few patients in two of the oldest studies. ${ }^{48,50}$

This article is protected by copyright. All rights reserved. 


\section{Operation time}

Operation time was significantly longer in the obese group in most comparative studies. 4-5, 11-12, 14-19, 21-24, 27, 29, 32-33 BMI was an independent predicting factor of the operation time in a multivariate analysis in two studies. ${ }^{11,21}$ Nevertheless, there were no statistical differences in twelve studies. $6,13,25-26,28,30-31,34-37,45$ Interestingly, one study reported a shorter mean operation time in the obese group, although the difference was not statistically significant. ${ }^{36}$ This study compared technical aspects and postoperative outcome in patients undergoing left hemicolectomy so the findings cannot not be generalised.

\section{Conversion}

The definition of conversion was very variable among the assessed studies. Conversion to an open procedure, according to each authors' definition, ranged between 0-29\% and it was similar in obese and non-obese patients in most studies. ${ }^{4}, 11-13,15-18,22,24,26,28,30-31$, 33-34, 36-37, 39-40, 46 Nevertheless, several studies reported a significantly higher conversion rate in obese patients $5-6,14,19-20,23,25,27,29,32,38,41-43,48-52$, which ranged between 10.8$45.8 \%$, compared with $2.6-14 \%$ in non-obese patients. Multivariate analysis showed obesity to be an independent predictor for conversion to open surgery, together with male gender, Crohn's disease (rather than ulcerative colitis) and intraoperative complications in a study involving various procedures for IBD including restorative proctocolectomy and ileoanal pouch formation. ${ }^{19}$ In another study of restorative proctocoloctomy with ileoanal pouch in patients with ulcerative colitis or familial polyposis, the risk of conversion was increased eight-fold by an increase in the BMI by 5 units. ${ }^{47}$ Similarly, obesity has been an independent predictor of conversion in a multivariate analysis. ${ }^{23}$

In three out of four studies that exclusively involved patients with rectal cancer, conversion was significantly higher in obese patients. ${ }^{20,23,29}$ Singh et al reported that conversions in obese patients were mostly in rectal cancer operations. ${ }^{25}$

This article is protected by copyright. All rights reserved. 


\section{The impact of conversion}

Few studies compared the outcome between converted and non-converted patients undergoing laparoscopic colorectal resections. Conversion was not associated with higher morbidity or longer hospital stay in four studies $22,29,41,49$, but others reported a worse outcome in converted cases. ${ }^{38,42-43,47-48}$ Marusch et al noted that more patients in the converted group required blood transfusion $(36 \%$ vs. $12 \%, \mathrm{p}<0.05)$ and had higher postoperative overall morbidity $(47.7 \%$ vs. $26.1 \%, \mathrm{p}<0.05) .{ }^{48}$ Conversion has also been associated with significantly longer operation time, greater blood loss and higher postoperative morbidity in some studies. ${ }^{38,43}$

Nineteen studies reported on blood loss. In eight of them, blood loss was significantly higher in the obese group, 12, 17, 19, 22-24, 27, 45 whereas there were no statistically significant differences in all other studies. ${ }^{6}, 11,13,15-16,26,30-31,33-34$ In those in which blood loss was significantly higher in obese patients, differences in mean blood loss were limited to $25-103 \mathrm{~mL}$, except in one study in which it was higher (mean $150 \mathrm{~mL}$ for BMI 25-30 vs. 500mL for BMI>30, $p=0.01) .{ }^{45}$

\section{The surgical incision}

Three studies reported that the length of the surgical incision was significantly longer in the obese patients compared with those with normal weight group. ${ }^{13,19,34}$ Differences in mean length were 4 vs. $4.5 \mathrm{~cm}(p=0.003){ }^{34}, 8.5$ vs. $9.6(p<0.001){ }^{19}$ and 5 vs. 6.9 $(p=0.02)$ in one study that compared patients with normal weight than those with a BMI of over $40 \mathrm{~kg} / \mathrm{m}^{2}{ }^{13}$

\section{POSTOPERATIVE PERIOD}

\section{Morbidity and mortality}

\section{Overall morbidity}

Morbidity tended to be higher in obese patients, but most studies did not show statistically significant differences in the overall incidence of postoperative complications. $4,11-17,19-20,22-23,26-34,36-37,39-40$ Nevertheless, other studies reported overall 
morbidity to be significantly higher in obese patients. ${ }^{5-6,14,18,24-25,44,47}$ Interestingly, in three of these studies higher morbidity did not correlate with longer hospital stay. ${ }^{5,14,18}$ An increased VFA was shown to be a predictive factor for postoperative complications, anastomotic leakage and surgical site infection in multivariate analysis. ${ }^{18}$

\section{Wound infection}

Most studies that reported specifically on wound infection showed no statistically significant differences between obese and non-obese patients. ${ }^{5}, 11-13,16,19,22-23,26-30,32-33$ Nevertheless, some investigators found significantly higher rates in the obese group. ${ }^{6}$, 14-15, 18, 21, 24-25 Wound infection was five times more frequent in obese patients in one study ${ }^{14}$, and obesity was an independent risk factor for wound infection in multivariate analysis in two other studies. ${ }^{15,21}$

\section{Postoperative ileus}

Few studies assessed the incidence of postoperative ileus and most did not find any statistically significant difference between obese and non-obese patients. ${ }^{11-13,16,22,24,27}$, ${ }^{32}$ In one study, ileus was significantly higher in the former $(32.3 \% v s .7 .6 \%, p<0.01)$ but it was not clear whether this correlated with a longer hospital stay. ${ }^{6}$ Another study reported more ileus in the obese group $(13 \%$ vs. $3 \%, \mathrm{p}<0.05)$ with hospital stay being more than double for obese patients converted to open surgery, although data provided in the study do not allow direct correlation between these two variables. ${ }^{25}$

\section{Cardiopulmonary complications}

Eight of the ten studies that reported cardiopulmonary complications did not find significant differences between obese and non-obese patients. ${ }^{6,11,13,16,21-22,31-32}$ Despite the use of mechanical ventilation with positive end-expiratory pressure (PEEP) to prevent postoperative atelectasis, Bège et al reported significantly more respiratory complications (atelectasis) in the obese group (3.2\% vs. $16.6 \%, \mathrm{p}=0.02) .{ }^{29}$ Systemic complications, especially pulmonary complications, were significantly higher in obese patients in another study, visceral obesity being the only significant independent risk factor for the development of systemic complications in the multivariate analysis. ${ }^{30}$

This article is protected by copyright. All rights reserved. 


\section{Anastomotic leakage}

Most of the 26 comparative studies with available data, showed no differences in the incidence of anastomotic leakage between obese and non obese patients, 6, 11-17, 19, 22-23, 25-34, 36-37 with only three studies reporting significantly higher rates of leakage in the former. ${ }^{5,18,24}$ One of these studies involved 1194 patients operated on for colorectal cancer and the multivariate analysis showed that rectal cancer and obese II group (BMI $>30$ ) were independent predictive factors for anastomotic leakage. ${ }^{24}$

\section{Reoperation}

Reoperation rates in obese and non-obese were similar in most of the studies in which this variable had been reported. $4,13-14,19,22,28,32-33,36-37$ Only one study reported significantly higher reoperation rates in the pre-obese (BMI 25-28) compared with non obese patients ( 2 out of 11 cases, $18.2 \%$ vs. 1 out of 49 cases, $2 \% ; p=0.047$ ), whereas there were no reoperations in the obese group. ${ }^{34}$ Two articles reported on reoperations for incarceration of small bowel into a port site but they were not in obese patients ${ }^{34}$ or they did not specify the group. ${ }^{31}$

\section{Long-term surgical outcome}

Very few articles reported on long-term surgical outcome. With a median follow-up of 37 months there were no differences between the incidence of incisional hernia in one study $(9 \% v s .9 \%, p>0.99)^{11}$, whereas it was significantly higher in obese patients in another at a mean follow up of 61 months $(4.7 \%$ vs. $0.6 \%, p=0.021) .{ }^{19}$ Singh et al reported two cases of incisional hernia formation in the obese group, while there were none in the non-obese, but the duration of follow-up was unclear. Another study did not find differences in the incidence of port-site hernia formation when comparing both groups but, likewise, length of follow-up was not specified. ${ }^{37}$

\section{Mortality}

None of the comparative studies that reported on mortality showed any statistically

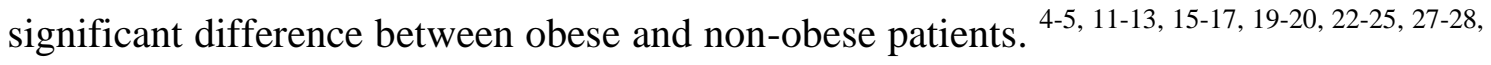
$31-33,37$

This article is protected by copyright. All rights reserved. 


\section{Hospital stay}

Most studies did not find any statistically significant difference in the length of hospital stay between obese and non-obese patients. 4-5, 11-16, 18-20, 22-23, 26, 28-32, 34-35, 37 A few studies reported a longer hospital stay in obese patients $6,21,24,27,33$ and in most it correlated with a higher morbidity in these patients. ${ }^{6,21,24,33}$ Singh et al did not find any difference in the proportion of laparoscopically completed cases, but hospital stay of converted cases was significantly longer in the obese. ${ }^{25}$ In one study the length of hospital stay was significantly shorter in the obese group ( $7 v s .9$ days, $\mathrm{p}<0.01){ }^{36}$

\section{ONCOLOGICAL DATA}

\section{Number of harvested lymph nodes}

Most of the sixteen studies that compared the oncological safety between obese and non obese patients showed no statistically significant difference in the number of retrieved lymph nodes (Table 2). ${ }^{11,15-17,25-26,29,31,34,36,38}$ Nevertheless, others have reported significantly fewer harvested lymph nodes, ${ }^{18,20,24}$ although the mean number of nodes was over 12 in all the groups. Park et al reported significantly higher harvested lymph nodes in non-obese patients compared with those with a BMI of $25-29.9 \mathrm{~kg} / \mathrm{m}^{2}(27.4 v s$. 24.3, $\mathrm{p}=0.004)$, but there were no differences between non obese patients and those with a BMI of over $30 \mathrm{~kg} / \mathrm{m}^{2}$ (27.4 vs. 26.2, $\left.\mathrm{p}=0.908\right) .{ }^{27}$ Interestingly, Kang et al reported significantly fewer patients with less than 12 retrieved lymph nodes in the obese group when they were classified according to the visceral fat area (VFA) $(65.5 \%$ vs. $34.5 \%, p=0.002$ ) but there were no differences when groups were based on BMI (43\% vs. $40 \%, p=0.73){ }^{23}$

\section{Long-term oncological outcome}

Few studies reported overall survival and disease-free survival (Table 2). ${ }^{11,20,23,25}$ Two studies on rectal cancer ${ }^{20,23,25}$ and two on colorectal cancer ${ }^{11,25}$ found no difference in overall survival and disease free survival between obese and non-obese patients.

This article is protected by copyright. All rights reserved. 


\section{DISCUSSION}

Advances in surgical expertise and technology have resulted in the increased uptake of laparoscopic surgery worldwide. ${ }^{55-56}$ Several studies point to its increasing acceptance in the treatment of colorectal cancer and benign colorectal conditions. ${ }^{57-59}$ Similarly, obesity has also been increasing worldwide with many clinicians describing it as an epidemic. ${ }^{60-61}$ The impact of obesity on the outcome of laparoscopic colorectal surgery is currently debated but this comprehensive systematic review has demonstrated that laparoscopic colorectal resection performed in obese patients is feasible, safe and reproducible with similar results compared with non-obese patients although the operation time is, unsurprisingly, prolonged. In conjunction with any unavoidable anaesthetic difficulty in intubation or ventilation this highlights the importance of careful preoperative planning including adequate operating theatre time and surgical assistance.

BMI has been used worldwide to define obesity, being over $30 \mathrm{~kg} / \mathrm{m}^{2}$ in the Western population according to the WHO classification ${ }^{53}$ Asian populations, however, have a higher proportion of body fat and prominent abdominal obesity compared with people of European origin with similar BMI values. ${ }^{62} \mathrm{~A}$ WHO consultation addressed this debate and a BMI of over $25 \mathrm{~kg} / \mathrm{m}^{2}$ is widely accepted as cut off for obesity in Asian populations. ${ }^{63}$ Also, BMI does not accurately correspond with intracorporeal fat distribution. ${ }^{64}$ This is particularly relevant to intra-abdominal surgery and laparoscopy from a technical point of view. The measurement of visceral obesity using the visceral fat area (VFA), measured by cross-sectional imaging, has been proposed as an alternative to BMI. ${ }^{33,65}$ There is a relation between VFA measured at the level of the umbilicus and total volume of visceral fat. ${ }^{66-67}$ The study by Kang et al has shown that visceral fat obesity is a more reliable predictor of outcome than BMI in patients undergoing laparoscopic total mesorectal excision. ${ }^{23}$ In this review, obesity was defined using BMI, but the cut-off point for obesity differed according to the geographical region of origin. European and American studies considered as obese those patients with a BMI of over $30 \mathrm{~kg} / \mathrm{m}^{2}$. 4-6, 11-14, 19-22, 25-26, 28-29, 31-32, 35-37, 39, 45 Most Asian studies defined obesity as a BMI over $25 \mathrm{~kg} / \mathrm{m}^{2} 15-16,18,23-24,27,30,33$ according to the Japanese Society for the Study of Obesity and the Steering Committee of the Regional Office for Western Pacific of the WHO ${ }^{54}$, whereas others considered patients to be obese with a BMI of over $22 \mathrm{~kg} / \mathrm{m}^{2}{ }^{17}$, or $28 \mathrm{~kg} / \mathrm{m}^{2} .{ }^{34}$ 
Obesity is associated with comorbidity including glucose intolerance, dyslipidemia, diabetes, hypertension, kidney failure and depression. ${ }^{68}$ The accompanying pathophysiological alterations in obese patients may result in intraoperative anaesthetic difficulties and perioperative management mainly from a respiratory point of view, due to reduced vital capacity, atelectasis, decreased chest wall compliance, hypoxaemia and water and electrolyte replacement. ${ }^{69}$ Co-morbidity was not systematically reported in all studies in this review and none of the studies reported intraoperative anaesthetic difficulties. Moreover, many of the postoperative problems which could have been expected to occur in obese patients such as hyperglycaemia have not been reported in the analysed publications.

The operation time was significantly longer in obese patients in a number of studies. ${ }^{4-5}$, 11-12, 14-19, 21-24, 27, 29, 32-33 BMI was an independent predicting factor for operation time in a multivariate analysis in two studies. ${ }^{11,21}$ The increased visceral fat in obese patients may contribute to the increased technical difficulty of the procedure with respect to visualization of vascular structures in the mesentery, mobilization of bowel and manoeuvering instruments in a restricted space. ${ }^{16,27}$ An important factor possibly contributing to a higher operation time is the surgeon's learning curve. Laparoscopic colorectal surgery is technically complex, with a lower adoption rate than other laparoscopic procedures and with an estimated learning curve of between 30 and 60 cases with some authors suggesting that larger numbers of cases are required to surpass the learning curve. ${ }^{52,70-71}$ The learning curve also has an impact on the conversion rate 8,43 , which in turn may influence postoperative morbidity. ${ }^{38,42-43}$ More effective simulation training in a risk-free environment could be used to reduce the learning curve. $^{72}$ Male gender associated with a narrower pelvis, previous irradiation, T4 tumours and lower location of the tumour have been shown to be associated with a higher conversion rate in laparoscopic rectal resection. ${ }^{43,45}$ These problems were once thought to support the adoption of robotic surgery to facilitate pelvic dissection in obese male patients, but the recently reported ROLARR trial which included at least 500 patients failed to demonstrate any significant benefit of robotic pelvic dissection. Conversion was also significantly associated with a longer operation time, greater blood loss and higher postoperative morbidity in other studies. ${ }^{38,43}$ In this review, the conversion rate in the studies ranged between 0-29\% and was similar in obese and non- 
obese patients in most of these. ${ }^{4,11-13,15-18,22,24,26,28,30-31,33-34,36-37,39-40,46}$ Some studies reported a significantly higher conversion rate in obese patients. $5-6,14,19-20,23,25,27,29,32$, $38,41-43,48-52$

Laparoscopic colorectal surgery offers the potential of early ambulation and oral intake and a shorter hospital stay. ${ }^{73}$ Enhanced recovery programmes, which are an important development in postoperative management ${ }^{75}$, have further reduced the postoperative hospital stay. ${ }^{76}$ There is, however, a shortage of studies investigating enhanced recovery programmes in laparoscopic colorectal surgery. ${ }^{77}$ In this review, the time to oral intake and ambulation was variable following an expectant approach 11, 17-19 and few studies followed a fast-track protocol or an enhanced recovery programme. ${ }^{25,29}$ Most studies in this review did not find any statistically significant difference in the length of hospital stay between obese and non obese patients. 4-5, 11-16, 18-20, 22-23, 26, 28-32, 34-35, 37 Singh et al found no difference in the laparoscopically completed cases, but hospital stay of the converted cases was significantly longer in obese patients. ${ }^{25}$

There were no significant differences in the obese and non-obese groups with respect to intraoperative blood loss, overall postoperative morbidity, anastomotic leakage, reoperation rate and mortality, which indicate that laparoscopic colorectal resection is safe and technically feasible in obese patients. Postoperative morbidity tended to be higher in obese patients, but most studies did not show statistically significant differences in the overall incidence of postoperative complications. 4, 11-17, 19-20, 22-23, 26-34, 36-37, 39-40 Some studies reported overall morbidity to be significantly higher in the obese $5-6,14,18,24-25,44,47$ and in three of these studies a higher morbidity did not correlate with a longer hospital stay. ${ }^{5,14,18}$ Increased VFA was shown to be a predictive factor for postoperative complications, anastomotic leakage and surgical site infection in a multivariate analysis. ${ }^{18}$

Most studies that reported specifically on wound infection showed no statistically significant differences between obese and non-obese patients 5, 11-13, 16, 19, 22-23, 26-30, 32-33 ,but few studies defined wound infection in accordance with the Centers for Disease Control (CDC) criteria 18, 21, 33 . Only a few studies assessed the incidence of postoperative ileus and most of these did not find any statistically significant difference between obese and non-obese patients. $11-13,16,22,24,27,32$ While one study reported a 
prolonged ileus in the obese group $(13 \%$ vs. $3 \%, \mathrm{p}<0.05)$ with hospital stay being more than double for obese patients converted to open surgery, the data provided in the study does not allow correlating these two variables. ${ }^{25}$ Most studies that reported on cardiopulmonary complications did not find any significant differences between obese and non-obese patients. ${ }^{6,11,13,16,21-22,31-32}$ The pathophysiological alterations in respiratory function that accompany obesity pose a challenge in postoperative management and Bège et al. reported significantly more respiratory complications (atelectasis) in the obese group ( $3.2 \%$ vs. $16.6 \%, \mathrm{p}=0.02) .{ }^{29}$ This occurred despite the use of mechanical ventilation with positive end-expiratory pressure (PEEP) to prevent postoperative atelectasis in this study.

Laparoscopic colorectal surgery gives comparable oncological results in the number of harvested lymph nodes, resection margin clearance, disease-free survival, overall survival and recurrence compared with open surgery. ${ }^{78-79}$ Most of the studies included in this review showed no difference in oncological parametres between obese and nonobese patients including the number of retrieved lymph nodes. ${ }^{11,15-17,25-26,29,31,34,36,38}$ Four studies did not find any difference in overall and disease free survival between obese and non-obese patients. 11, 20, 23, 25 This indicates that laparoscopic colorectal surgery is oncologically feasible, but further studies investigating the long-term oncological outcome are warranted.

One of the most complex colorectal operations might be restorative proctocolectomy (RPC). Efron et al compared 31 obese with 31 non-obese patients who underwent this operation laparoscopically ${ }^{80}$. They reported not only a significantly higher longer operation time but also a significantly higher rate of postoperative pelvic sepsis in the obese group. Thus, not all data can be extrapolated to all clinical situations. Similarly, Kinle et $a l^{45}$, noted a a higher conversion rate in patients with an "elevated BMI" undergoing laparoscopic RPC.

This detailed systematic review of the literature has demonstrated that laparoscopic colorectal resection is safe and technically and oncologically feasible in obese patients, but the results may be different in regional colorectal units compared with high volume centres of excellence. 
Figure 1. - PRISMA diagram illustrating the search strategy
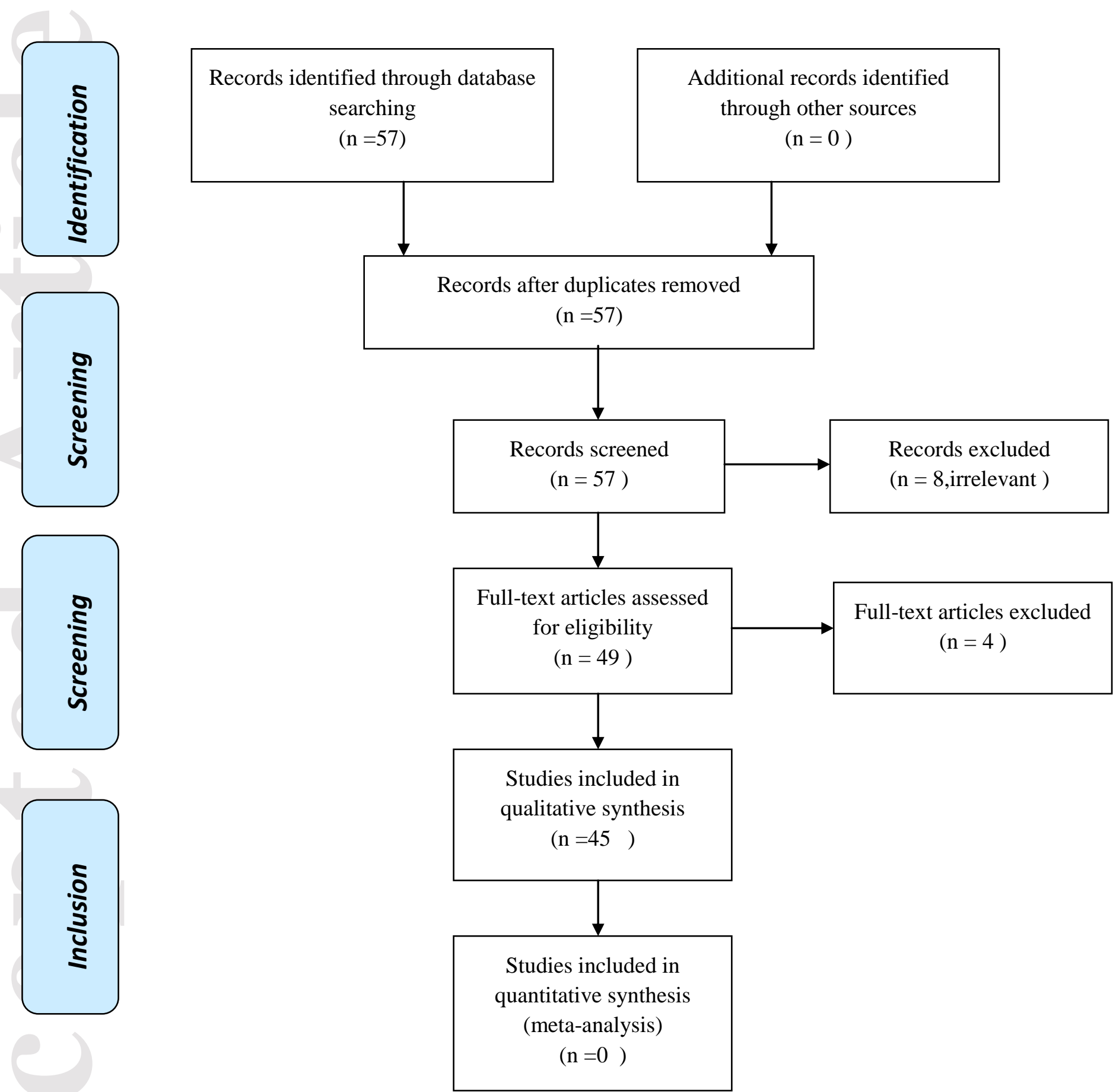

This article is protected by copyright. All rights reserved. 
Table 1. - Summary of studies investigating the impact of obesity and body-mass index on the outcome of laparoscopic colorectal surgery

\begin{tabular}{|c|c|c|c|c|c|c|c|c|c|}
\hline suthoer & veor & $n$ & $\begin{array}{l}\text { Desegr and } \\
\text { Endence level }\end{array}$ & 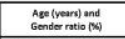 & 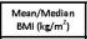 & Doersting time (rins) & Conversion rote & 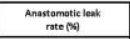 & 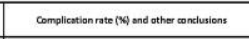 \\
\hline Moriteral" & 2015 & st & 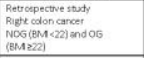 & 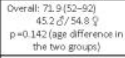 & $\operatorname{Man} 22.6$ & 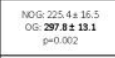 & $\infty x=0 \%$ & $\infty \times v=0 \%$ & 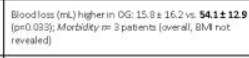 \\
\hline 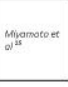 & 2014 & 561 & 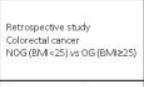 & 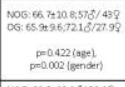 & $\operatorname{Mean} 229$ & 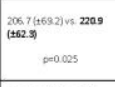 & 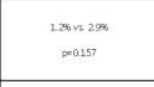 & 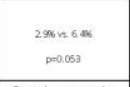 & 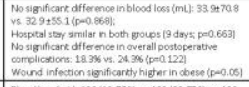 \\
\hline xioental" & 2014 & 527 & 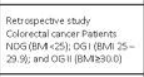 & 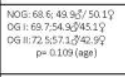 & $\operatorname{Man} 230+32$ & 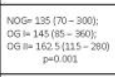 & $\begin{array}{c}268 v=278 v v: 125 \% \\
\approx 0.113\end{array}$ & 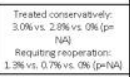 & 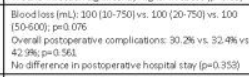 \\
\hline 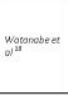 & 2014 & 338 & 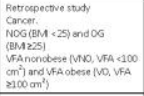 & 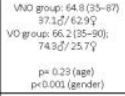 & Men $229 t 32$ & 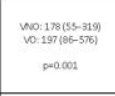 & 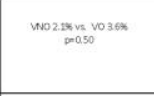 & 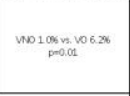 & 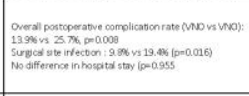 \\
\hline Mathoerad & 2014 & 152 & 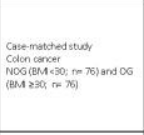 & 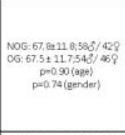 & 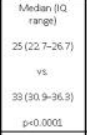 & 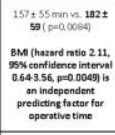 & $\sin =20(p<0.099)$ & 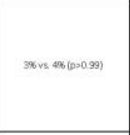 & 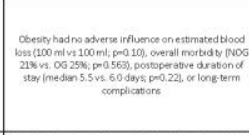 \\
\hline Kronesetaly & 2013 & 626 & 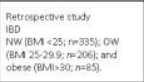 & 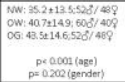 & 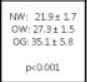 & 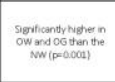 & 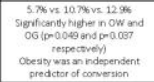 & 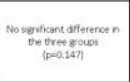 & 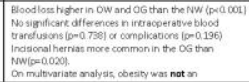 \\
\hline
\end{tabular}

\begin{tabular}{|c|c|c|c|c|c|c|c|c|c|}
\hline & & & & & & & & & 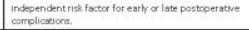 \\
\hline pernosiced al & 2013 & 400 & 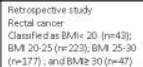 & 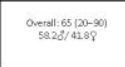 & 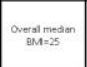 & Na & 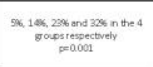 & 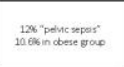 & 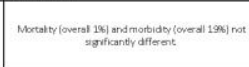 \\
\hline Hosseted" & 2013 & 160 & 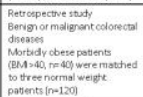 & 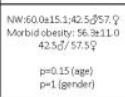 & 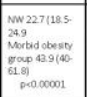 & 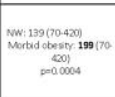 & $\underset{p=0.15}{25807}$ & $\underset{=1}{12706.25 s}$ & 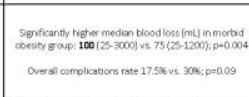 \\
\hline sustan ex af & 2012 & 9680 & 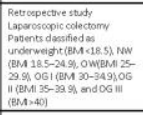 & 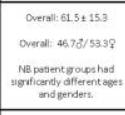 & 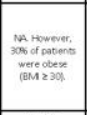 & 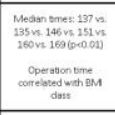 & Na & Na & 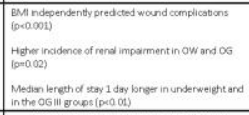 \\
\hline 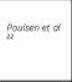 & 2012 & $4 x$ & 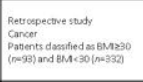 & 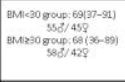 & 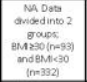 & 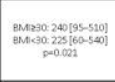 & 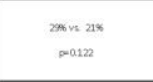 & 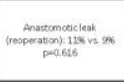 & 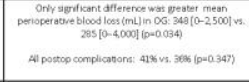 \\
\hline kangerta $\alpha^{2}$ & 202 & 142 & 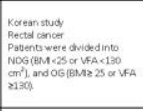 & 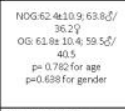 & 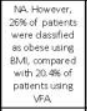 & 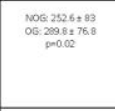 & 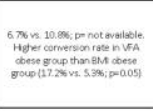 & 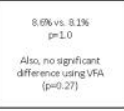 & 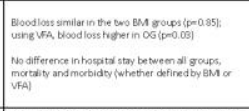 \\
\hline 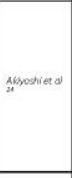 & 2011 & 1194 & 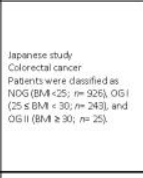 & 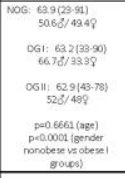 & 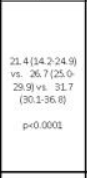 & 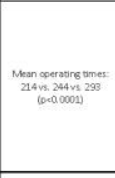 & 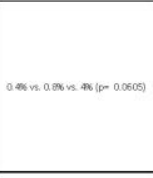 & 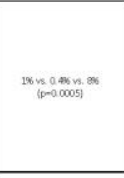 & 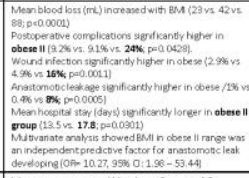 \\
\hline singher $a^{t^{3}}$ & 2011 & 234 & 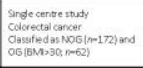 & 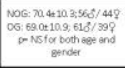 & 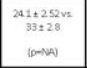 & 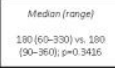 & 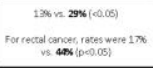 & $\cos x \cdot 1 \operatorname{sos}(\theta-1)$ & 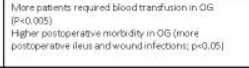 \\
\hline
\end{tabular}




\begin{tabular}{|c|c|c|c|c|c|c|c|c|c|}
\hline & & & & & & & & & 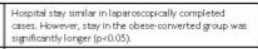 \\
\hline 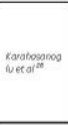 & 2011 & 100 & 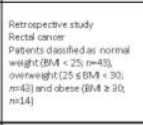 & 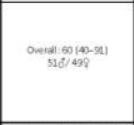 & 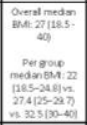 & 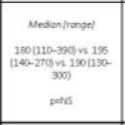 & 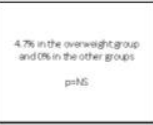 & 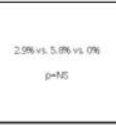 & 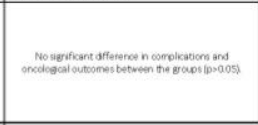 \\
\hline Avikete d" & 2000 & 994 & 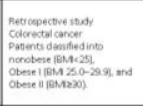 & 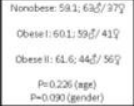 & 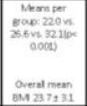 & 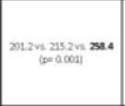 & 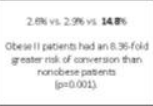 & 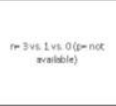 & 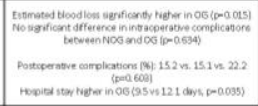 \\
\hline Seribereal & 2000 & 262 & 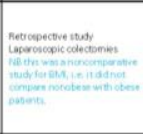 & 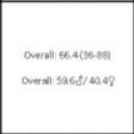 & 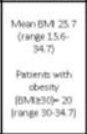 & 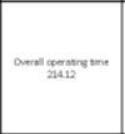 & 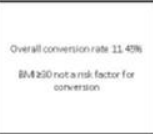 & zim atent & 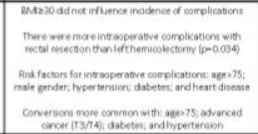 \\
\hline Sanesebetal & 2000 & 213 & 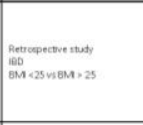 & 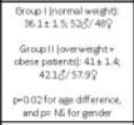 & 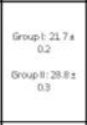 & 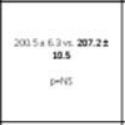 & $\lim _{0 \rightarrow 15} 22 x$ & $\sin _{\sin 2}$ & 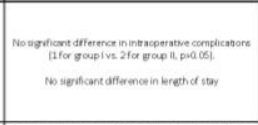 \\
\hline toloberent af & 2000 & $s$ & 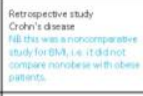 & 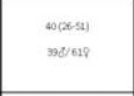 & 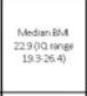 & 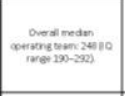 & 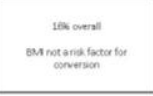 & 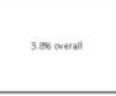 & 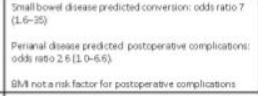 \\
\hline growines d & 2010 & 72 & 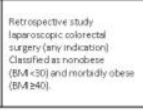 & 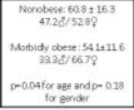 & 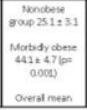 & 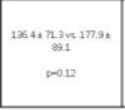 & 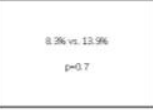 & 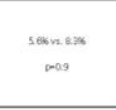 & 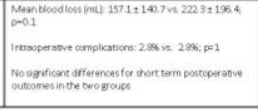 \\
\hline
\end{tabular}

\begin{tabular}{|c|c|c|c|c|c|c|c|c|c|}
\hline & & & & & $B=44$ & & & & 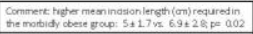 \\
\hline 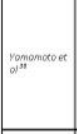 & 2000 & 1003 & 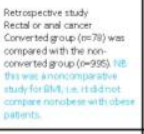 & 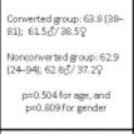 & 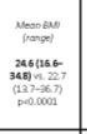 & 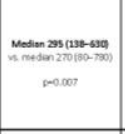 & 7somownt & 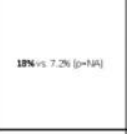 & 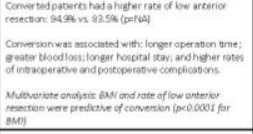 \\
\hline expect a $d^{\circ}$ & 2000 & 210 & 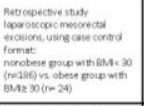 & 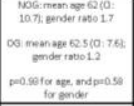 & 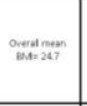 & 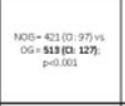 & 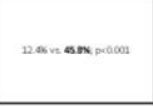 & in & 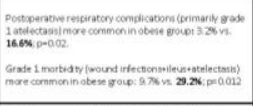 \\
\hline ramaonere of & 2000 & 100 & 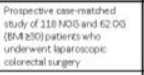 & 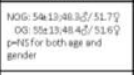 & 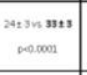 & 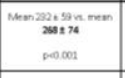 & 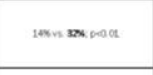 & 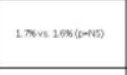 & 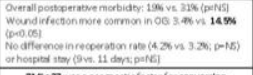 \\
\hline fortove al al & 2000 & ${ }^{17 n}$ & 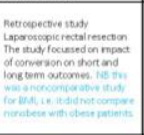 & 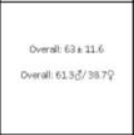 & 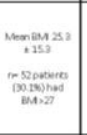 & $\mid$ & 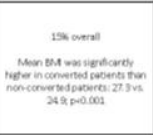 & 130 onetalt & 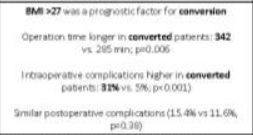 \\
\hline axter tea a & 2000 & $\approx$ & 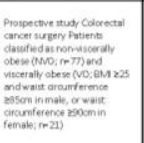 & 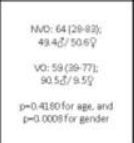 & 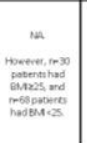 & 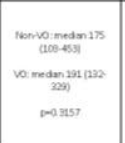 & 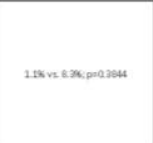 & 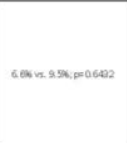 & 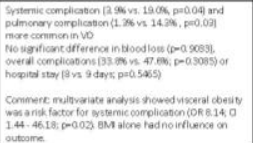 \\
\hline \begin{tabular}{|l} 
Alusberget \\
and
\end{tabular} & 2000 & 8 & 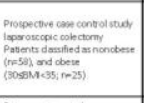 & 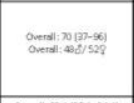 & 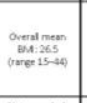 & 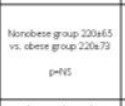 & 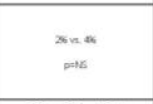 & $\operatorname{arn} 0 \mathrm{~s}$ & 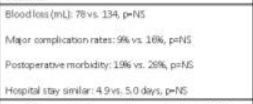 \\
\hline \begin{tabular}{|l} 
Schentacth \\
\end{tabular} & \begin{tabular}{|l|l|}
2000 \\
\end{tabular} & 5568 & Retercepecture tsudf & Derall: $021(351-444)$ & Nockenonded & 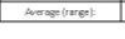 & $55 \% x=79 x+13 x$ & Entititeresed & 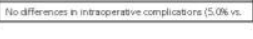 \\
\hline
\end{tabular}




\begin{tabular}{|c|c|c|c|c|c|c|c|c|c|}
\hline etorits & & & 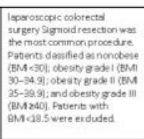 & 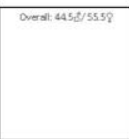 & 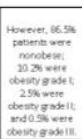 & 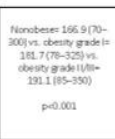 & posoot & 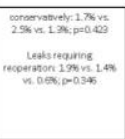 & 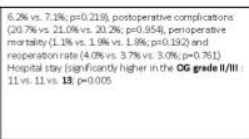 \\
\hline Thopeet al & 2000 & 400 & 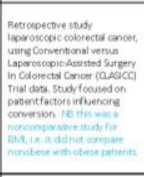 & 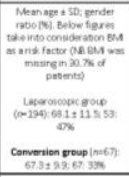 & 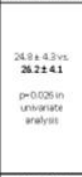 & in & 290 roverd & in & 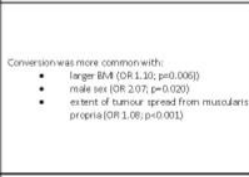 \\
\hline Aphoet a d" & 2000 & 200 & 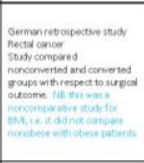 & 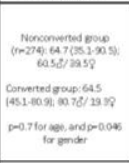 & 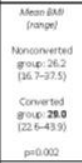 & 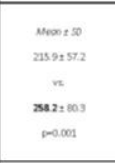 & 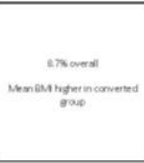 & me & 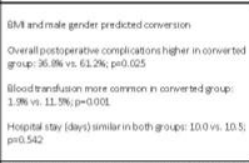 \\
\hline 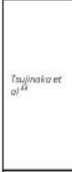 & 200 & 139 & 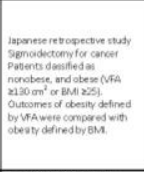 & 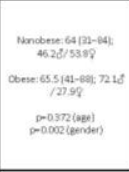 & 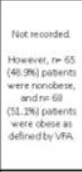 & 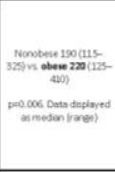 & 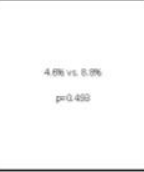 & 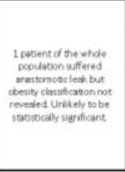 & 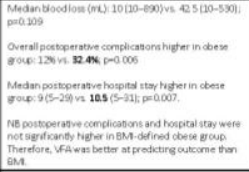 \\
\hline 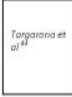 & 2000 & $\omega$ & 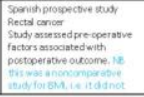 & 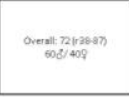 & 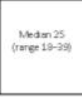 & $127(00-30)$ & 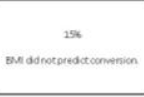 & in & 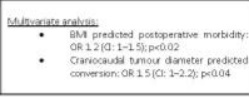 \\
\hline
\end{tabular}

\begin{tabular}{|c|c|c|c|c|c|c|c|c|c|}
\hline & & & 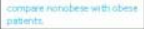 & & & & & & \\
\hline remontereat & 2006 & so & 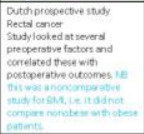 & 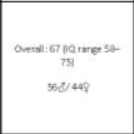 & 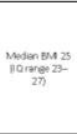 & 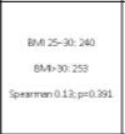 & in & in & 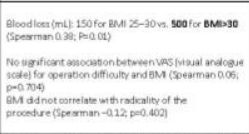 \\
\hline 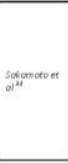 & 2000 & $\omega$ & 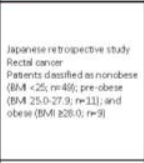 & 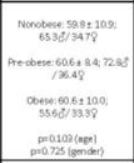 & 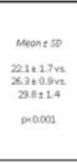 & 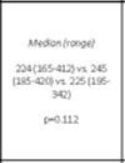 & 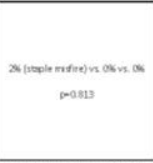 & 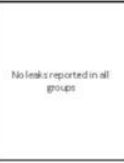 & 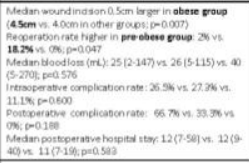 \\
\hline reitsengol" & 2006 & 900 & 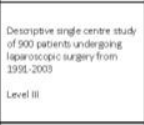 & 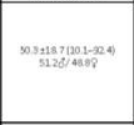 & 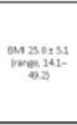 & 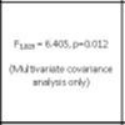 & 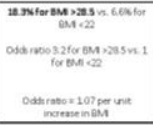 & in & 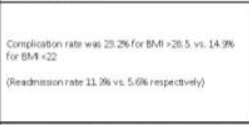 \\
\hline Dourtalie tol & 2005 & $4 \% 5$ & 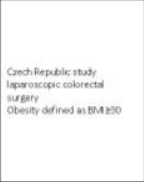 & 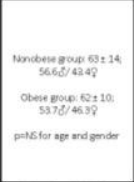 & 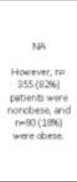 & 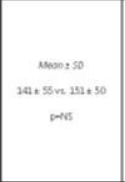 & 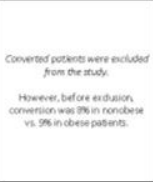 & 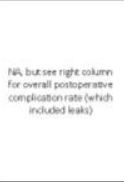 & 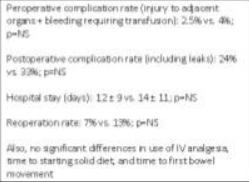 \\
\hline teropered" & 2005 & 1111 & 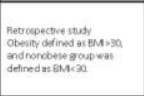 & 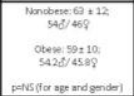 & 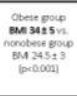 & 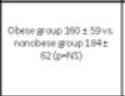 & 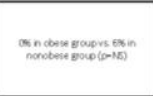 & 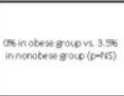 & 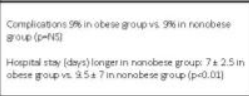 \\
\hline
\end{tabular}




\begin{tabular}{|c|c|c|c|c|c|c|c|c|c|}
\hline 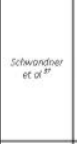 & 2004 & ses & 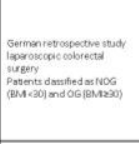 & 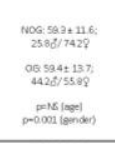 & 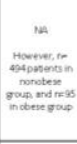 & 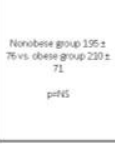 & 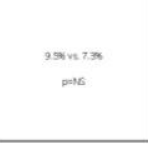 & 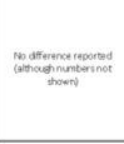 & 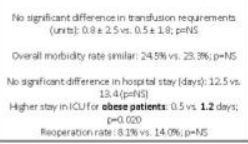 \\
\hline 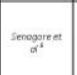 & 2000 & 260 & 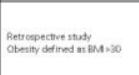 & 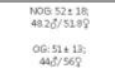 & 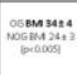 & 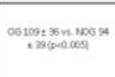 & OGXatur & 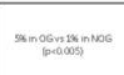 & 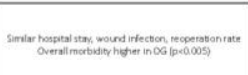 \\
\hline 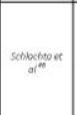 & 2000 & 240 & 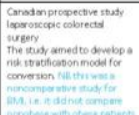 & sect/sesp & 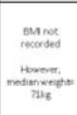 & is & $8 m$ & in & 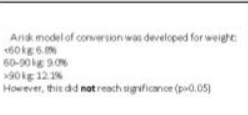 \\
\hline comient a & 2000 & 5 & 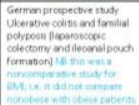 & 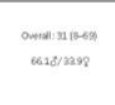 & 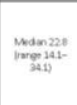 & $\underset{\operatorname{mis}}{\operatorname{mon}}$ & 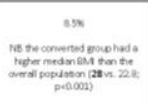 & $10 \mathrm{x}$ & 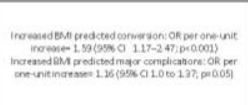 \\
\hline pxossyetal a & 2000 & 162 & 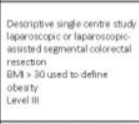 & 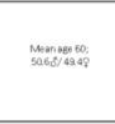 & 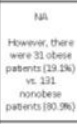 & 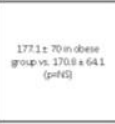 & 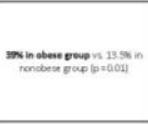 & 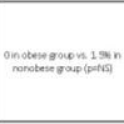 & 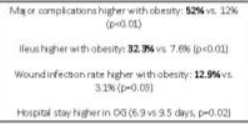 \\
\hline Marushet ad & 2000 & $16 e$ & 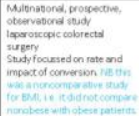 & 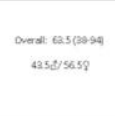 & is & ia & 520 & $15 \mathrm{sa}$ & 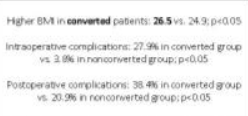 \\
\hline \begin{tabular}{|l|} 
Tuestet of \\
\end{tabular} & 2001 & $\pi$ & 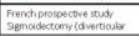 & 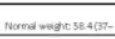 & \begin{tabular}{|l|l|l} 
Hoct hoodeded \\
\end{tabular} & $187 \times 5$ 210W: 20 & 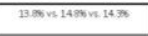 & 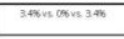 & 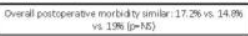 \\
\hline
\end{tabular}

\begin{tabular}{|c|c|c|c|c|c|c|c|c|c|}
\hline & & & 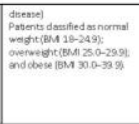 & 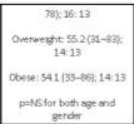 & 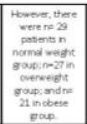 & 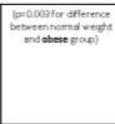 & pents & perta & 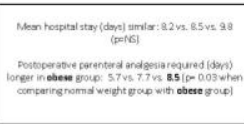 \\
\hline 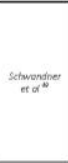 & 1000 & 300 & 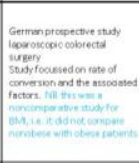 & $\begin{array}{l}624(127-99) \\
223 \& 7278\end{array}$ & 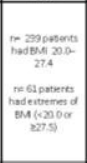 & iA & natomat & Na & 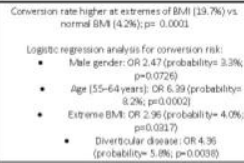 \\
\hline Fonstgeneal & 1900 & 200 & 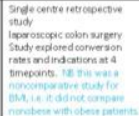 & is & in & aA & 2258 oreath & ra & 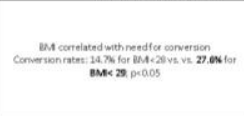 \\
\hline Desenertaf" & 1904 & 122 & 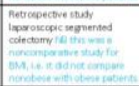 & in & in & 14 & 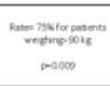 & in & 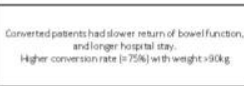 \\
\hline
\end{tabular}

OG obese group; NOG non obese group; VOG viscerally obese group; VNOG viscerally non obese group; NW normal weight; OW overweigth; VFA visceral fat area 
Table 2. Histopathological assessment of the surgical specimen based on BMI in patients who underwent laparoscopic colectomy for cancer OG obese group; NOG non-obese group; VOG viscerally obese group: VNOG viscerally non obese group

\begin{tabular}{|c|c|c|c|c|c|c|}
\hline Author & Year & $\begin{array}{c}\text { Number of resections } \\
\text { for cancer } \\
\text { (obese vs. nonobese) }\end{array}$ & TNM staging & $\begin{array}{l}\text { Number of lymph } \\
\text { nodes harvested }\end{array}$ & $\begin{array}{c}\text { Resection } \\
\text { margins } \\
(\mathrm{cm})\end{array}$ & $\begin{array}{l}\text { Oncological } \\
\text { Outcomes }\end{array}$ \\
\hline Moriet $a 1^{17}$ & 2015 & $\begin{array}{l}31(O G=19) \\
\text { Right colon cancer }\end{array}$ & \begin{tabular}{|l|} 
No difference in \\
primary tumour stage \\
$(\mathrm{p}=0.756)$, size $(\mathrm{p}=0.614$ \\
) or histology type \\
$(\mathrm{p}-0.320)$
\end{tabular} & $\begin{array}{l}26.9 \pm 2.9 \text { vs. } 23.0 \pm 2.3 \\
p=0.290\end{array}$ & NA & \\
\hline $\begin{array}{l}\text { Miyamoto } \\
\text { et a }\left.\right|^{15}\end{array}$ & 2014 & $\begin{array}{l}561(O G=140) \\
\text { Colorectal cancer }\end{array}$ & $\begin{array}{l}\text { No difference in } \\
\text { primary tumour stage } \\
(p=0.074)\end{array}$ & $\begin{array}{l}\text { Mean }( \pm 5 D): 25.5( \pm 11.4) \\
\text { vs. } 24.3( \pm 12.8) \\
p=0.353\end{array}$ & \begin{tabular}{|l|} 
Equivalent \\
in both \\
groups (p= \\
0.412)
\end{tabular} & \\
\hline Xia et al $1^{16}$ & 2014 & $\begin{array}{l}527(O G \mid=142 ; O G \|= \\
14) \\
\text { Colorectal cancer }\end{array}$ & \begin{tabular}{|l} 
No difference in \\
primary tumour stage \\
$(\mathrm{p}=0.861)$
\end{tabular} & $\begin{array}{l}13(1-79) \text { vs. } 12(1-36) \text { vs. } \\
15(4-26) \\
p=0.111\end{array}$ & NA & \\
\hline $\begin{array}{l}\text { Watanabe } \\
\text { et al }\left.\right|^{18}\end{array}$ & 2014 & $\begin{array}{l}338 \text { (VOG n=144) } \\
\text { Colon cancer }\end{array}$ & $\begin{array}{c}\text { Vo } \\
\text { Stage 1/I117.5\% } \\
\text { Stage III/IV 28.5\% } \\
\text { vNo } \\
\text { Stage 1/11174.7\% } \\
\text { Stage III//V 25.3\% }\end{array}$ & $\begin{array}{c}\text { Vo group }=23.6(2-76) \\
\text { VNO group }=30.8(9-92) \\
p<0.001\end{array}$ & NA & \\
\hline$\underset{a^{21}}{\text { Makinoet }}$ & 2014 & $\begin{array}{l}152(O G=76) \\
\text { Colon cancer }\end{array}$ & $\begin{array}{l}\text { No difference in final } \\
\text { TNM stage }(p=0.90)\end{array}$ & $\begin{array}{c}\text { OG= median } 17.0(13.3- \\
21.8) \\
\text { NOG= median } 17.0(13.3- \\
21.0) \\
\mathrm{p}=0.97\end{array}$ & NA & 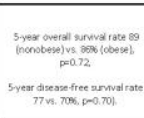 \\
\hline
\end{tabular}

\begin{tabular}{|c|c|c|c|c|c|c|}
\hline Denostetal & 2013 & $\begin{array}{l}490 \text { patients classified by } \\
\text { BMI (<20; 20-25; } 25-30 \text {; } \\
\text { 230) } \\
\text { Rectal cancer }\end{array}$ & $\begin{array}{l}\text { No difference in stage } \\
\quad(p=0.243)\end{array}$ & $\begin{array}{l}\text { Significantly higher } \\
\text { number of nodes } \\
\text { analysed in group with } \\
\text { BMI230 (p=0.031) }\end{array}$ & $\begin{array}{c}\text { No } \\
\text { difference } \\
(p=0.497)\end{array}$ & 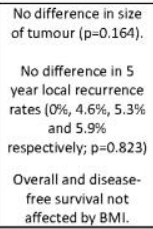 \\
\hline Kanget al & 2012 & 142 & $\begin{array}{l}\text { No difference in TNM } \\
\text { staging } \\
\text { OG: pathological } \\
\text { complete response } \\
\text { (pCR) or T1 or T2 = } \\
37.8 \% \\
\text { T3 or T4= } 62.2 \% \\
\text { NOG: pCR or T1 or T2= } \\
41.9 \% \\
\text { T3 or T4 }=58.1 \% \\
\end{array}$ & $\begin{array}{l}\% \text { patients with < } 12 \\
\text { nodes harvested: } \\
\text { voG } 65.5 \% \text { vs. vNOG } \\
34.5 \% \text { (p } 0.002) \text {. } \\
\text { However, no difference } \\
\text { seen in BMI-defined OG } \\
\text { and NOG (43\% vs. 40\%, } \\
p=0.73 \text { ) }\end{array}$ & NA & 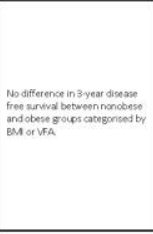 \\
\hline $\begin{array}{l}\text { Akivoshiet } \\
a l^{24}\end{array}$ & 2011 & $\begin{array}{l}1194 \text { (OG } \mid \mathrm{n}=243 ; 0 \mathrm{OG} \| \\
\mathrm{n}=25 \text { ) } \\
\text { Colorectal cancer }\end{array}$ & $\begin{array}{l}\text { No difference in final } \\
\text { TNM stage ( } p=0.1925)\end{array}$ & $\begin{array}{l}\text { Mean number of } \\
\text { harvested Iymph nodes } \\
\text { tended to be higher in } \\
\text { nonoobese group than in } \\
\text { the obese } \\
\text { land obese II groups } \\
\text { (11.8 } 5.16 .0 \text { and } 14.7 ; \\
p=0.0310 \\
\text { and } 0.0524 \text {, respectively) }\end{array}$ & NA & \\
\hline Singhetal & 2011 & $\begin{array}{l}\text { 62 vs. 172. Laparoscopic } \\
\text { colorectal surgery for } \\
\text { cancer. }\end{array}$ & Similar in both groups & $\begin{array}{l}10.3 \pm 4.6 \text { vs. } 11.2 \pm 5.7 \\
(\mathrm{p}=\mathrm{NS})\end{array}$ & $\begin{array}{l}\text { Equivalent } \\
\text { in both } \\
\text { Broups }\end{array}$ & 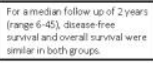 \\
\hline $\begin{array}{l}\text { Karahasano } \\
\text { gluet of } \text { I }^{6-}\end{array}$ & 2011 & $\begin{array}{l}100 \text { patients had } \\
\text { laparoscopic surgery for }\end{array}$ & \begin{tabular}{|l|} 
No significant \\
difference in TNM stage \\
\end{tabular} & No significant difference & $\begin{array}{l}\text { No } \\
\text { difference }\end{array}$ & \\
\hline
\end{tabular}

This article is protected by copyright. All rights reserved. 


\begin{tabular}{|c|c|c|c|c|c|}
\hline & & 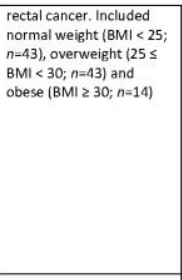 & & & $\begin{array}{l}\text { in proximal } \\
\text { or radial } \\
\text { margins. } \\
\text { Median } \\
\text { distal } \\
\text { margin } \\
\text { greater in } \\
\text { overweight } \\
\text { vs. normal } \\
\text { and obese } \\
\text { groups (3 } \\
\text { vs.2.5 vs. } \\
2.5 ; p<0.05)\end{array}$ \\
\hline Parket of ${ }^{27}$ & 2010 & 984 & $\begin{array}{l}\text { Of the } 975 \\
\text { Adenocarcinomas } \\
\text { reviewed: no significant } \\
\text { difference in stage } \\
(\mathrm{p}=0.081)\end{array}$ & $\begin{array}{l}27.4 \text { (nonobese) vs. } 24.3 \\
\text { (obese I) vs. } 26.2 \text { (obese } \\
\text { II) } \\
\text { ( } p=0.004 \text { comparing } \\
\text { nonobese and obese 1) }\end{array}$ & . \\
\hline $\begin{array}{l}\text { Yamamoto } \\
\text { et al }\end{array}$ & 2009 & $\begin{array}{l}1073 \text { patients underwent } \\
\text { surgerv for anal or rectal } \\
\text { cancer (n } n 78 \text { required } \\
\text { conversion v5. 995 } \\
\text { nonconverted cases). } \\
\text { Mean BMI was higher in } \\
\text { converted group. }\end{array}$ & $\begin{array}{l}\text { No overall difference in } \\
\text { stage }(p=0.193)\end{array}$ & $\begin{array}{l}\text { Median (range) } \\
16 \text { (0-84) vs. } 15 \text { (0-52); } \\
p=0.260\end{array}$ & $\begin{array}{l}\text { Distal } \\
\text { margins } \\
\text { equivalent } \\
\text { (p=0.573) }\end{array}$ \\
\hline Bège et al & 2009 & $\begin{array}{l}24 \text { vs. } 186 \text { had mesorectal } \\
\text { excisions }\end{array}$ & $\begin{array}{l}\text { No overall difference in } \\
\text { stage }(p=0.17)\end{array}$ & $\begin{array}{l}\text { Obese } 14.3 \text { (7.5) vs. } \\
\text { nonobese } 12.7(6.1) \text {; } \\
p=0.23\end{array}$ & $\begin{array}{l}\text { Equivalent } \\
\text { in both } \\
\text { groups }\end{array}$ \\
\hline $\begin{array}{l}\text { Blumberg } \\
\text { et } a^{1 / 1}\end{array}$ & 2009 & $\begin{array}{l}83 \text { patients ( } n=25 \text { obese } \\
\text { vs } n=58 \text { nonobese) } \\
\text { underwent laparoscopic } \\
\text { colectomy for cancer or } \\
\text { polys excluding T4 } \\
\text { tumours, obstructing } \\
\text { tumours, and rectal } \\
\text { tumors. }\end{array}$ & NA & $\begin{array}{l}\text { Obese } 13 \pm 6 \text { vs. } 11 \pm 6 \\
(p=N S)\end{array}$ & $\begin{array}{l}\text { Surgical } \\
\text { margins } \\
\text { were } \\
\text { negative in } \\
\text { all patients }\end{array}$ \\
\hline
\end{tabular}

\begin{tabular}{|c|c|c|c|c|c|}
\hline $\begin{array}{l}\text { Sakamoto } \\
\text { et } a^{135}\end{array}$ & 2007 & $\begin{array}{l}\text { obese ( }(n=9) \text { vs, preobese } \\
\text { (n=11) vs. nonobese } \\
(n-49) \text { had laparoscopic } \\
\text { anterior resection for } \\
\text { sigmoid/rectum cancer }\end{array}$ & $\begin{array}{l}\text { No overall difference in } \\
\text { stage }(p=0.517)\end{array}$ & $\begin{array}{l}\text { obese } 10(4-16) \text { vs. } \\
\text { preobese } 12(2-28) \text { vs. } \\
\text { nonobese } 14(2-47) ; \\
p=0.305\end{array}$ & NA \\
\hline Leroyet al & 2005 & 9 vs. 42 & $\begin{array}{l}\mathrm{OG:} n=2(25 \%) \text { spT2; } \\
n=6(75 \%)>\mathrm{pT2} \\
\text { NOG: } n=11(26 \%) \leq \mathrm{pT} 2 \\
\mathrm{n}=31(74 \%)>\mathrm{pT2} \\
\text { (NS) }\end{array}$ & $\begin{array}{l}7.2 \pm 6.4 \text { vs. } 9.1 \pm 5.5 \\
(\mathrm{p}=\mathrm{NS})\end{array}$ & $\begin{array}{l}5.1 \pm 8.5 \text { vs. } \\
7.2 \pm 3.8 \\
\text { (NS) }\end{array}$ \\
\hline
\end{tabular}

This article is protected by copyright. All rights reserved. 


\section{REFERENCES}

1. World Health Organisation. http://www.who.int/mediacentre/factsheets/fs311/en/. Website accessed 27th January 2015.

2. The English National training programme for laparoscopic colorectal surgery. http://lapco.nhs.uk. Website accessed 27th January 2015.

3. Nguyen NT, Goldman C, Rosenquist CJ, Arango A, Cole CJ, Lee SJ, Wolfe BM. Laparoscopic versus open gastric bypass: a randomized study of outcomes, quality of life, and costs. Annals of surgery 2001;234:279-89; discussion 89-91.

4. Tuech JJ, Regenet N, Hennekinne S, Pessaux P, Bergamaschi R, Arnaud JP. Laparoscopic colectomy for sigmoid diverticulitis in obese and nonobese patients: a prospective comparative study. Surgical endoscopy 2001;15:1427-30.

5. Senagore AJ, Delaney CP, Madboulay K, Brady KM, Fazio VW. Laparoscopic colectomy in obese and nonobese patients. Journal of gastrointestinal surgery : official journal of the Society for Surgery of the Alimentary Tract 2003;7:558-61.

6. Pikarsky AJ, Saida Y, Yamaguchi T, Martinez S, Chen W, Weiss EG, Nogueras JJ, Wexner SD. Is obesity a high-risk factor for laparoscopic colorectal surgery? Surgical endoscopy 2002;16:855-8.

7. Hazebroek EJ, Color Study G. COLOR: a randomized clinical trial comparing laparoscopic and open resection for colon cancer. Surgical endoscopy 2002;16:949-53.

8. Marusch F, Gastinger I, Schneider C, Scheidbach H, Konradt J, Bruch HP, Kohler L, Barlehner E, Kockerling F, Laparoscopic Colorectal Surgery Study G. Experience as a factor influencing the indications for laparoscopic colorectal surgery and the results. Surgical endoscopy 2001;15:116-20.

9. Hazebroek EJ. COLOR: a randomized clinical trial comparing laparoscopic and open resection for colon cancer. Surg Endosc 2002;16:949-53.

10. Marusch F, Gastinger I, Schneider C, Scheidbach H, Konradt J, Bruch HP, Kohler L, Barlehner $E$, Kockerling F. Experience as a factor influencing the indications for laparoscopic colorectal surgery and the results. Surg Endosc 2001;15:116-20.

11. Makino T, Trencheva K, Shukla PJ, Rubino F, Zhuo C, Pavoor RS, Milsom JW. The influence of obesity on short- and long-term outcomes after laparoscopic surgery for colon cancer: a case-matched study of 152 patients. Surgery 2014;156:661-8.

12. Haas EM AA, Nieto J et al. . Minimally Invasive Colorectal Surgery in the Morbidly Obese: Does High Body Mass Index Lead to Poorer Outcomes? . Surgery Curr Res 2013;3.

13. Khoury W, Kiran RP, Jessie T, Geisler D, Remzi FH. Is the laparoscopic approach to colectomy safe for the morbidly obese? Surgical endoscopy 2010;24:1336-40.

14. Kamoun S, Alves A, Bretagnol F, Lefevre JH, Valleur P, Panis Y. Outcomes of laparoscopic colorectal surgery in obese and nonobese patients: a case-matched study of 180 patients. American journal of surgery 2009;198:450-5.

15. Miyamoto $Y$, Ishii T, Tashiro J, Satoh T, Watanabe M, Baba H, Yamaguchi S. Effects of obesity on the outcome of laparoscopic surgery for colorectal cancer. Surgery today 2014;44:1293-9.

16. Xia X, Huang C, Jiang T, Cen G, Cao J, Huang K, Qiu Z. Is laparoscopic colorectal cancer surgery associated with an increased risk in obese patients? A retrospective study from China. World journal of surgical oncology 2014;12:184.

17. Mori S, Baba K, Yanagi M, Kita Y, Yanagita S, Uchikado Y, Arigami T, Uenosono Y, Okumura H, Nakajo A, Maemuras K, Ishigami S, Natsugoe S. Laparoscopic complete mesocolic excision with radical lymph node dissection along the surgical trunk for right colon cancer. Surgical endoscopy 2015;29:34-40.

18. Watanabe J, Tatsumi K, Ota M, Suwa $Y$, Suzuki S, Watanabe A, Ishibe A, Watanabe K, Akiyama $\mathrm{H}$, Ichikawa $\mathrm{Y}$, Morita $\mathrm{S}$, Endo I. The impact of visceral obesity on surgical outcomes of laparoscopic surgery for colon cancer. International journal of colorectal disease 2014;29:343-

This article is protected by copyright. All rights reserved. 
51.

19. Krane MK, Allaix ME, Zoccali M, Umanskiy K, Rubin MA, Villa A, Hurst RD, Fichera A. Does morbid obesity change outcomes after laparoscopic surgery for inflammatory bowel disease? Review of 626 consecutive cases. Journal of the American College of Surgeons 2013;216:986-96.

20. Denost Q, Quintane L, Buscail E, Martenot M, Laurent C, Rullier E. Short- and long-term impact of body mass index on laparoscopic rectal cancer surgery. Colorectal disease : the official journal of the Association of Coloproctology of Great Britain and Ireland 2013;15:463-9. 21. Mustain WC, Davenport DL, Hourigan JS, Vargas HD. Obesity and laparoscopic colectomy: outcomes from the ACS-NSQIP database. Diseases of the colon and rectum 2012;55:429-35.

22. Poulsen $\mathrm{M}$, Ovesen $\mathrm{H}$. Is laparoscopic colorectal cancer surgery in obese patients associated with an increased risk? Short-term results from a single center study of 425 patients. Journal of gastrointestinal surgery : official journal of the Society for Surgery of the Alimentary Tract 2012;16:1554-8.

23. Kang J, Baek SE, Kim T, Hur H, Min BS, Lim JS, Kim NK, Lee KY. Impact of fat obesity on laparoscopic total mesorectal excision: more reliable indicator than body mass index. International journal of colorectal disease 2012;27:497-505.

24. Akiyoshi $T$, Ueno $M$, Fukunaga $Y$, Nagayama $S$, Fujimoto $Y$, Konishi $T$, Kuroyanagi $H$, Yamaguchi T. Effect of body mass index on short-term outcomes of patients undergoing laparoscopic resection for colorectal cancer: a single institution experience in Japan. Surgical laparoscopy, endoscopy \& percutaneous techniques 2011;21:409-14.

25. Singh A, Muthukumarasamy G, Pawa N, Riaz AA, Hendricks JB, Motson RW. Laparoscopic colorectal cancer surgery in obese patients. Colorectal disease : the official journal of the Association of Coloproctology of Great Britain and Ireland 2011;13:878-83.

26. Karahasanoglu T, Hamzaoglu I, Baca B, Aytac E, Kirbiyik E. Impact of increased body mass index on laparoscopic surgery for rectal cancer. European surgical research Europaische chirurgische Forschung Recherches chirurgicales europeennes 2011;46:87-93.

27. Park JW, Lim SW, Choi HS, Jeong SY, Oh JH, Lim SB. The impact of obesity on outcomes of laparoscopic surgery for colorectal cancer in Asians. Surgical endoscopy 2010;24:1679-85.

28. Canedo J, Pinto RA, Regadas S, Regadas FS, Rosen L, Wexner SD. Laparoscopic surgery for inflammatory bowel disease: does weight matter? Surgical endoscopy 2010;24:1274-9.

29. Bege T, Lelong B, Francon D, Turrini O, Guiramand J, Delpero JR. Impact of obesity on short-term results of laparoscopic rectal cancer resection. Surgical endoscopy 2009;23:1460-4.

30. Nitori N, Hasegawa H, Ishii Y, Endo T, Kitagawa Y. Impact of visceral obesity on shortterm outcome after laparoscopic surgery for colorectal cancer: a single Japanese center study. Surgical laparoscopy, endoscopy \& percutaneous techniques 2009;19:324-7.

31. Blumberg D. Laparoscopic colectomy performed using a completely intracorporeal technique is associated with similar outcome in obese and thin patients. Surgical laparoscopy, endoscopy \& percutaneous techniques 2009;19:57-61.

32. Scheidbach H, Benedix F, Hugel O, Kose D, Kockerling F, Lippert H. Laparoscopic approach to colorectal procedures in the obese patient: risk factor or benefit? Obesity surgery 2008;18:66-70.

33. Tsujinaka S, Konishi F, Kawamura YJ, Saito M, Tajima N, Tanaka O, Lefor AT. Visceral obesity predicts surgical outcomes after laparoscopic colectomy for sigmoid colon cancer. Diseases of the colon and rectum 2008;51:1757-65; discussion 65-7.

34. Sakamoto K, Niwa S, Tanaka M, Goto M, Sengoku H, Tomiki Y. Influence of obesity on the short-term outcome of laparoscopic colectomy for colorectal cancer. Journal of minimal access surgery 2007;3:98-103.

35. Dostalik J, Martinek L, Vavra P, Andel P, Gunka I, Gunkova P. Laparoscopic colorectal surgery in obese patients. Obesity surgery 2005;15:1328-31.

36. Leroy J, Ananian P, Rubino F, Claudon B, Mutter D, Marescaux J. The impact of obesity

This article is protected by copyright. All rights reserved. 
on technical feasibility and postoperative outcomes of laparoscopic left colectomy. Annals of surgery 2005;241:69-76.

37. Schwandner O, Farke S, Schiedeck TH, Bruch HP. Laparoscopic colorectal surgery in obese and nonobese patients: do differences in body mass indices lead to different outcomes? Surgical endoscopy 2004;18:1452-6.

38. Yamamoto S, Fukunaga M, Miyajima N, Okuda J, Konishi F, Watanabe M, Japan Society of Laparoscopic Colorectal S. Impact of conversion on surgical outcomes after laparoscopic operation for rectal carcinoma: a retrospective study of 1,073 patients. Journal of the American College of Surgeons 2009;208:383-9.

39. Del Rio P, Dell'Abate P, Gomes B, Fumagalli M, Papadia C, Coruzzi A, Leonardi F, Pucci $\mathrm{F}$, Sianesi M. Analysis of risk factors for complications in 262 cases of laparoscopic colectomy. Annali italiani di chirurgia 2010;81:21-30.

40. Holubar SD, Dozois EJ, Privitera A, Pemberton JH, Cima RR, Larson DW. Minimally invasive colectomy for Crohn's colitis: a single institution experience. Inflammatory bowel diseases 2010;16:1940-6.

41. Rottoli M, Bona S, Rosati R, Elmore U, Bianchi PP, Spinelli A, Bartolucci C, Montorsi M. Laparoscopic rectal resection for cancer: effects of conversion on short-term outcome and survival. Annals of surgical oncology 2009;16:1279-86.

42. Thorpe H, Jayne DG, Guillou PJ, Quirke P, Copeland J, Brown JM, Medical Research Council Conventional versus Laparoscopic-Assisted Surgery In Colorectal Cancer Trial G. Patient factors influencing conversion from laparoscopically assisted to open surgery for colorectal cancer. The British journal of surgery 2008;95:199-205.

43. Agha A, Furst A, lesalnieks I, Fichtner-Feigl S, Ghali N, Krenz D, Anthuber M, Jauch KW, Piso P, Schlitt HJ. Conversion rate in 300 laparoscopic rectal resections and its influence on morbidity and oncological outcome. International journal of colorectal disease 2008;23:40917.

44. Targarona EM, Balague C, Pernas JC, Martinez C, Berindoague R, Gich I, Trias M. Can we predict immediate outcome after laparoscopic rectal surgery? Multivariate analysis of clinical, anatomic, and pathologic features after 3-dimensional reconstruction of the pelvic anatomy. Annals of surgery 2008;247:642-9.

45. Veenhof AA, Engel AF, van der Peet DL, Sietses C, Meijerink WJ, de Lange-de Klerk ES, Cuesta MA. Technical difficulty grade score for the laparoscopic approach of rectal cancer: a single institution pilot study. International journal of colorectal disease 2008;23:469-75.

46. Schlachta CM, Mamazza J, Gregoire R, Burpee SE, Pace KT, Poulin EC. Predicting conversion in laparoscopic colorectal surgery. Fellowship training may be an advantage. Surgical endoscopy 2003;17:1288-91.

47. Kienle P, Weitz J, Benner A, Herfarth C, Schmidt J. Laparoscopically assisted colectomy and ileoanal pouch procedure with and without protective ileostomy. Surgical endoscopy 2003;17:716-20.

48. Marusch F, Gastinger I, Schneider C, Scheidbach H, Konradt J, Bruch HP, Kohler L, Barlehner E, Kockerling F, Laparoscopic Colorectal Surgery Study G. Importance of conversion for results obtained with laparoscopic colorectal surgery. Diseases of the colon and rectum 2001;44:207-14; discussion 14-6.

49. Schwandner $\mathrm{O}$, Schiedeck $\mathrm{TH}$, Bruch $\mathrm{H}$. The role of conversion in laparoscopic colorectal surgery: Do predictive factors exist? Surgical endoscopy 1999;13:151-6.

50. Pandya S, Murray JJ, Coller JA, Rusin LC. Laparoscopic colectomy: indications for conversion to laparotomy. Archives of surgery 1999;134:471-5.

51. Dean PA, Beart RW, Jr., Nelson H, Elftmann TD, Schlinkert RT. Laparoscopic-assisted segmental colectomy: early Mayo Clinic experience. Mayo Clinic proceedings 1994;69:834-40.

52. Tekkis PP, Senagore AJ, Delaney CP, Fazio VW. Evaluation of the learning curve in laparoscopic colorectal surgery: comparison of right-sided and left-sided resections. Annals of surgery 2005;242:83-91.

This article is protected by copyright. All rights reserved. 
53. Obesity: preventing and managing the global epidemic. Report of a WHO consultation. World Health Organization technical report series 2000;894:i-xii, 1-253.

54. Examination Committee of Criteria for 'Obesity Disease' in J, Japan Society for the Study of $O$. New criteria for 'obesity disease' in Japan. Circulation journal : official journal of the Japanese Circulation Society 2002;66:987-92.

55. Zaidi A, Sharma S. The athlete's heart. British journal of hospital medicine (London, England : 2005) 2011;72:275-81.

56. Schlussel AT, Lustik MB, Johnson EK, Maykel JA, Champagne BJ, Goldberg JE, Steele SR. Do the advantages of a minimally invasive approach remain in complex colorectal procedures? A nationwide comparison. Diseases of the colon and rectum 2015;58:431-43.

57. Bonjer HJ, Hop WC, Nelson H, Sargent DJ, Lacy AM, Castells A, Guillou PJ, Thorpe H, Brown J, Delgado S, Kuhrij E, Haglind E, Pahlman L. Laparoscopically assisted vs open colectomy for colon cancer: a meta-analysis. Archives of surgery 2007;142:298-303.

58. Causey MW, Stoddard D, Johnson EK, Maykel JA, Martin MJ, Rivadeneira D, Steele SR. Laparoscopy impacts outcomes favorably following colectomy for ulcerative colitis: a critical analysis of the ACS-NSQIP database. Surgical endoscopy 2013;27:603-9.

59. Messenger DE, Mihailovic D, MacRae HM, O'Connor BI, Victor JC, McLeod RS. Subtotal colectomy in severe ulcerative and Crohn's colitis: what benefit does the laparoscopic approach confer? Diseases of the colon and rectum 2014;57:1349-57.

60. Lopez-Candales A, Dohi K, lliescu A, Peterson RC, Edelman K, Bazaz R. An abnormal right ventricular apical angle is indicative of global right ventricular impairment. Echocardiography 2006;23:361-8.

61. Ogden CL, Carroll MD, Kit BK, Flegal KM. Prevalence of obesity among adults: United States, 2011-2012. NCHS Data Brief 2013:1-8.

62. He Q, Horlick M, Thornton J, Wang J, Pierson RN, Jr., Heshka S, Gallagher D. Sex and race differences in fat distribution among Asian, African-American, and Caucasian prepubertal children. J Clin Endocrinol Metab 2002;87:2164-70.

63. Appropriate body-mass index for Asian populations and its implications for policy and intervention strategies. Lancet 2004;363:157-63.

64. Bouchard C, Despres JP, Mauriege P. Genetic and nongenetic determinants of regional fat distribution. Endocr Rev 1993;14:72-93.

65. Ishii $\mathrm{Y}$, Hasegawa $\mathrm{H}$, Nishibori $\mathrm{H}$, Watanabe $\mathrm{M}$, Kitajima $\mathrm{M}$. Impact of visceral obesity on surgical outcome after laparoscopic surgery for rectal cancer. The British journal of surgery 2005;92:1261-2.

66. Tokunaga $\mathrm{K}$, Matsuzawa $\mathrm{Y}$, Ishikawa $\mathrm{K}$, Tarui $\mathrm{S}$. A novel technique for the determination of body fat by computed tomography. Int J Obes 1983;7:437-45.

67. Kvist H, Chowdhury B, Sjostrom L, Tylen U, Cederblad A. Adipose tissue volume determination in males by computed tomography and 40K. Int J Obes 1988;12:249-66.

68. Martin-Rodriguez E, Guillen-Grima F, Marti A, Brugos-Larumbe A. Comorbidity associated with obesity in a large population: The APNA study. Obes Res Clin Pract 2015.

69. Pelosi P, Gregoretti C. Perioperative management of obese patients. Best Pract Res Clin Anaesthesiol 2010;24:211-25.

70. Miskovic D, Ni M, Wyles SM, Tekkis P, Hanna GB. Learning curve and case selection in laparoscopic colorectal surgery: systematic review and international multicenter analysis of 4852 cases. Diseases of the colon and rectum 2012;55:1300-10.

71. Bardakcioglu O, Khan A, Aldridge C, Chen J. Growth of laparoscopic colectomy in the United States: analysis of regional and socioeconomic factors over time. Annals of surgery 2013;258:270-4.

72. Celentano V. Need for simulation in laparoscopic colorectal surgery training. World J Gastrointest Surg 2015;7:185-9.

73. Guillou PJ, Quirke P, Thorpe H, Walker J, Jayne DG, Smith AM, Heath RM, Brown JM. Short-term endpoints of conventional versus laparoscopic-assisted surgery in patients with

This article is protected by copyright. All rights reserved. 
colorectal cancer (MRC CLASICC trial): multicentre, randomised controlled trial. Lancet 2005;365:1718-26.

74. Trastulli S, Cirocchi R, Listorti C, Cavaliere D, Avenia N, Gulla N, Giustozzi G, Sciannameo F, Noya G, Boselli C. Laparoscopic vs open resection for rectal cancer: a metaanalysis of randomized clinical trials. Colorectal disease : the official journal of the Association of Coloproctology of Great Britain and Ireland 2012;14:e277-96.

75. Kehlet H. Fast-track surgery-an update on physiological care principles to enhance recovery. Langenbecks Arch Surg 2011;396:585-90.

76. Basse L, Hjort Jakobsen D, Billesbolle P, Werner M, Kehlet H. A clinical pathway to accelerate recovery after colonic resection. Annals of surgery 2000;232:51-7.

77. Dhruva Rao PK, Howells S, Haray PN. Does an enhanced recovery programme add value to laparoscopic colorectal resections? Int J Colorectal Dis 2015;30:1473-7.

78. Vennix S, Pelzers L, Bouvy N, Beets GL, Pierie JP, Wiggers T, Breukink S. Laparoscopic versus open total mesorectal excision for rectal cancer. Cochrane Database Syst Rev 2014;4:CD005200.

79. Sajid MS, Ahamd A, Miles WF, Baig MK. Systematic review of oncological outcomes following laparoscopic vs open total mesorectal excision. World J Gastrointest Endosc 2014;6:209-19.

80. Efron JE, Uriburu JP, Wexner SD, Pikarsky A, Hamel C, Weiss EG, Nogueras JJ. Restorative proctocolectomy with ileal pouch anal anastomosis in obese patients. Obes Surg 2001;11:246-51.

This article is protected by copyright. All rights reserved. 